\title{
EVOLUTION OF ENVIRONMENT AND HUMAN HABITATION IN MARAMUREŞ FROM THE NEOLITHIC TO THE EARLY MIDDLE AGE ${ }^{1}$
}

\section{AN OVERVIEW}

\author{
Aurel Rustoiu
}

DOI: https://doi.org/10.31577/szausav.2019.suppl.1.25

Keywords: natural environments, settlements, cemeteries, Maramureş, Romania, Transcarpathian Ukraine, mineral resources

Evolution of environment and human habitation in Maramureş from the Neolithic to the early Middle Age : An overwiew

The natural environment influences the manner in which different communities organize their structures of habitatiaon and economic activities. At the same time, the anthropic factor could also play an important role in environmental changes. The manner in which people perceive the environment is contributing to the appearance of certain social attitudes and practices, and also to the development of particular strategies aiming to transform the landscape according to the needs of local communities. Accordingly, the article aims to discuss a series of relevant elements regarding the development and distribution of human habitations in the Maramureş depression, on the upper Tisza River, from the Neolithic to the early Middle Age on the basis of the relationships between the natural and the anthropic environment.

\section{INTRODUCTION}

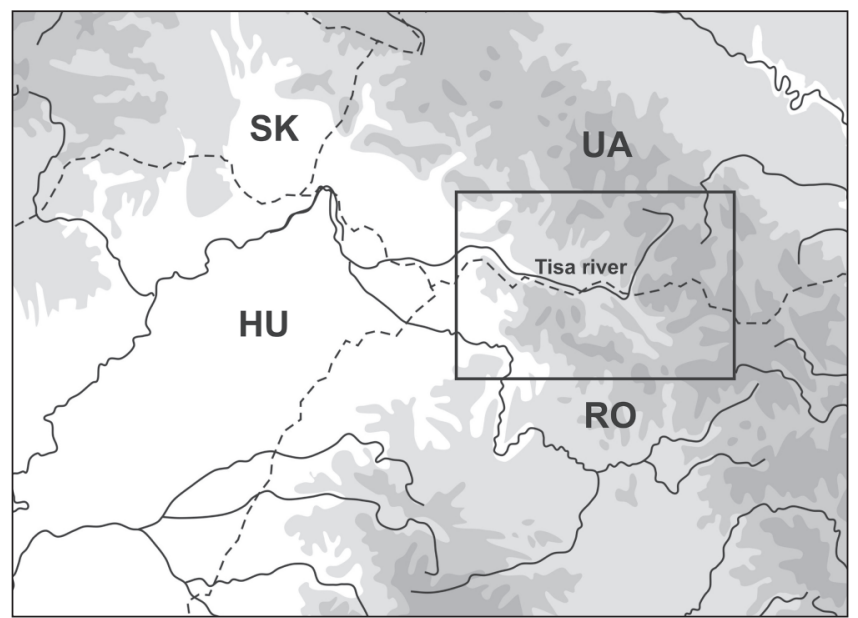

Fig. 1. Location of the Maramureş depression.

The natural environment influences the manner in which different communities organize their structures of habitation and economic activities. At the same time, the anthropic factor could play an important role in environmental changes. Along the same lines, the manner in which people perceive the environment is contributing to the appearance of certain social attitudes and practices, and also to the development of particular strategies aiming to transform the landscape according to the needs of local communities. These relationships between the natural and the anthropic environment provide the starting point for an analysis focusing on the development and distribution of human habitations in the Maramureş depression during different historical periods.

The scientific interests of Elena Miroššayová, whose activity is celebrated in this volume, has covered various aspects related to the Iron Age in south-eastern Slovakia, a region connected in prehistory with the upper Tisza basin. Therefore, a succinct analysis of the aforementioned aspects from the Maramureş depression, on the upper Tisza River, would be a fitting homage to her outstanding scientific achievements.

\footnotetext{
1 This work was supported by a grant of Ministry of Research and Innovation, CNCS - UEFISCDI, project number PN-III-P4-
} ID-PCE-2016-0353, within PNCDI III. 


\section{GEOGRAPHY OF MARAMUREŞ DEPRESSION}

Maramureş is one of the largest depressions inside the Carpathians range, covering an area of around $10000 \mathrm{~km}^{2}$. The depression has a north-west - south-east orientation and is delimited geo-morphologically by mountain ranges having various heights; it covers areas in modern northern Romania and Transcarpathian Ukraine (Fig. 1; see further details in Corpade 2011; Hamar/Sárkány-Kiss 1999; Kacsó 2011a, 66-77; Oancea et al. 1987; Popa 1970, 34-41; Posea 2005; 1982; etc.).

From the hydrographical perspective, the depression is split into two unequal parts by the upper Tisza River which flows from the east to the west, leaving the region through a short gorge. To the south, the most important tributaries are the Vişeu and the Iza rivers. The northern tributaries are more numerous, with the Taras, the Talabor and the Neagova rivers having more substantial debits. Other shorter tributaries of the Tisza also contribute to the fragmentation of the region. The corresponding valleys are bordered by high hills, some of them forming gorges and others delimitating small depressions. Thus the entire region is divided into several micro-zones which in the past had an important role in the structural organization of human habitats and their economic territory. In general, these valleys have a width of a few hundred metres, only occasionally reaching $1 \mathrm{~km}$. Still, in the Sighet region the Tisza River flows toward a wider plain that have a width of up to $4-5 \mathrm{~km}$ (see Fig. 5), but is gradually narrower toward Hust.

In spite of the particular geography that suggests a certain degree of isolation, the Maramureş depression is connected with the surrounding regions through some passes across the mountains that were also used in the past. The easiest access route followed the Tisza River through the so-called "Gate of Hust". It is not a coincidence that at the end of the Late Iron Age, during the Dacian kingdom, the access along this route was controlled by the settlement and fortress at Malaja Kopanija, while during the Middle Age the same role was played by the fortress at Hust.

To the east and south-east the access routes followed some river valleys in Maramureş upstream across the mountains, even when they reached an altitude of over $2000 \mathrm{~m}$ and a width of ca. $100 \mathrm{~km}$, then going downstream along the river valleys in Moldova. These routes were already used in prehistory, as some archaeological finds sporadically identified in these mountain passes seem to suggest (Dragoman et al. 2015). They were still used in the Middle Age, being mentioned in documents (Popa 1970, 240-247; Sălăgean 2006, 198-201).

The geo-morphological layout of the depression strongly influence the local climate and vegetation. Thus the higher mountains from the east and the landscape opening to the west and north-west contribute to the preponderance of a humid climate specific to Central Europe. In general, the Maramureş depression has a lower average annual temperature in comparison with the nearby regions to the south or west.

The local vegetation is also influenced by the hilly and mountainous landscape. Nowadays numerous areas are deforested, but at the end of the $18^{\text {th }}$ century vast areas were still covered by forests, which were marked on the Austrian imperial topographic maps (Josephinische Landesaufnahme 2014). They are also documented earlier, in a medieval diploma of 1299 which mentions the Hungarian king hunting in Maramureş in the "royal forest" (Popa 1970, 45, 46). Lastly, these forests could have been part of the "silva Hercinia" described by C. Julius Caesar in $1^{\text {st }}$ century BC. While writing about its extent, Caesar (BG VI, $25,1-4)$ mentions that the forest begins at the border of the Helvetii lands and extends along the Danube down to the territories of the Dacians and the Anartes, where it leaves the river and continues toward other peoples' lands.

Some recent paleoclimatic analyses performed in the upper Tisza basin provide some data that helps reconstructing the natural environment of the last millennia (Feurdean et al. 2012; Sümegi 1999; Sümegi et al. 2002; Willis et al. 1998). For example, the vegetation evolved in accordance with the macroor micro-regional climatic conditions, albeit the human factor also determined major changes in the general features of the natural environment. In the regions closer to Maramureş (mostly in north-eastern Hungary), the impact of this factor was already visible in Neolithic but grew stronger starting with the Bronze Age (mostly in lowland areas, since in the mountains the impact of human activity is only visible during the last two millennia) and became irreversible from the end of the Iron Age until today. Some investigations dealing with the evolution of vegetation on the western slopes of the Gutâi Mountains, toward the Oaş depression which is located westward from Maramureş, at an altitude of over $700 \mathrm{~m}$, are relevant (Feurdean/Astaloş 2005). It was observed that during the early and middle Bronze Age oak forests also containing hazelnut, elm and linden, specific to a warmer and drier climate, were suddenly 
replaced by forests dominated by beech associated with hornbeam, oak, hazelnut and birch. At the end of the $2^{\text {nd }}$ millennium $B C$, beech forests witnessed their maximum extension, indicating a more humid climate. The rapid rising proportion of the beech to the detriment of other tree species was also noted in north-eastern Hungary during the same period (Sümegi 1999, 187). For the $1^{\text {st }}$ millennium BC, the same analyses point to a reduction of the area occupied by beech forests and a proportional increasing of the Scots pine, birch, oak, hazelnut and willow. During the following periods, in the $1^{\text {st }}$ millennium AD and also later, the palynological diagram shows a reduction in the forests' diversity and their gradual degradation, as well as the appearance of cereals and flax, which signal the impact of human intervention on the environment. The increasing concentration of charcoal micro-particles also indicates the influence of human factor on the transformation of natural environment due to the use of fire to clear lands for agriculture and animal husbandry. The palynological diagram for the Maramureş mountains, sampled at an altitude of over $1500 \mathrm{~m}$, displays in general the same evolution of the vegetation. At the same time, it is relevant that traces of cereals occur more consistently in the Early Iron Age and similar patterns are only identified again in the last millennium. The impact of human activity is also demonstrated by traces of the deforestations carried out during the Iron Age (Fărcaş et al. 2013).

Accordingly, the landscape and vegetation characteristics were significantly influenced in the past by the spatial distribution and density of the settlements, among other things. In this case, a statistical analysis of the finds belonging to the last millennia in Maramureş would be useful to estimate the impact of human factor on the natural environment and also to understand the ways in which this environment influenced the establishing and structural organization of human habitats.

\section{THE ANTHROPIC ENVIRONMENT - EVOLUTION OF HUMAN HABITATS}

The density of settlements estimated by mapping the known sites is directly related to the state of archaeological research in the Maramureş depression. Unfortunately the region has seen no major infrastructure works which would have allowed large-scale archaeological investigations. However, some systematic archaeological excavations and field surveys carried out on the Romanian part of Maramureş contributed to the identification of several archaeological sites belonging to different periods. They are listed in the recently published archaeological repertoire of the Maramureş County (see Kacsó 2011a with bibliography; some small additions in Pop 2015). In the part of Maramureş to the north of the Tisza River, most archaeological investigations were small-scale. These were concentrated mostly in areas along the Tisza and the results were published in different studies and monographs (Kacsó 2007; 2011b; 2013; Kobal 1996; Kotigoroško 1995; Popovich 1997; Vasiliev et al. 2002 etc.).

Thus the distribution area of the identified archaeological sites is strongly influenced by the state of research. The list of sites taken into consideration for statistical analysis is based on data from C. Kacsó (2011a), which includes previous bibliography; the discoveries from Transcarpathian Ukraine were also added - see the aforementioned bibliography. However, their spatial and temporal distribution, as well as the estimated average frequency of sites per century could provide a relevant image of the intensity of habitation in the Maramureş depression through time (Table 1).

The Neolithic sites are located along the Tisza River, as well as on the Iza valley and some of its tributaries. The intensity of habitation was very low, with an average number of ca. 0.34 sites per century (Fig. 2: 1).

During the following period, at the end of the Eneolithic and the beginning of the Bronze Age, the settlements continued to be sporadic, with an average number of ca. 0.14 sites per century, which is even lower than that of the Neolithic. Two settlements belonging to the Cotsofeni culture were identified in the Sighet region. They are important for marking the northern extension of the area occupied by populations belonging to this culture. On the other hand, their presence on the upper Tisza, far away from the main distribution area of the Cotofeni culture, point to the mobility of the respective communities, more likely due to their pastoral lifestyle. However, the Maramureş depression continued to be largely uninhabited during this period (Fig. 2: 2).

The middle and late Bronze Age witnessed the highest density of settlements in the Maramureş depression, a pattern which was only surpassed at the beginning of the Middle Age. A total number of 40 sites were identified, with an average number of four sites per century. Culturally, the discoveries belong to the first and second phases of the Suciu de Sus culture. Similarly to other historical periods, the 
settlements were located in the Sighet region, on both banks of the Tisza and on the lateral valleys to the south and the north of the river. Others were identified along the Iza valley and on some of its tributaries, as well as on the Vişeu valley (Fig. 3). Topographically, the settlements were located on river banks or terraces, in floodless places that also had access to fertile agricultural lands. R. Popa noted that a series of early medieval settlements superposed the Bronze Age ones (Popa 1970). This fact indicates a similar pattern of organizing the habitat and its agricultural surroundings. Lastly, the sudden demographic increasing in comparison with the previous periods may indicate the migration of Suciu de Sus communities from the nearby regions to the Maramureş depression.

Table. 1. Statistics of the settlements from Maramureş during each historical period. Black - number of settlements/period; grey - average number/century.

\begin{tabular}{|l|l|l|l|}
\hline \multicolumn{1}{|c|}{ Age } & \multicolumn{1}{c|}{ Chronology } & No. settlements & \multicolumn{1}{c|}{ Average/century } \\
\hline Neolithic & $7000 / 6000-3500 \mathrm{BC}$ & 12 & 0.34 \\
\hline EBA & $3500-2200 / 2100 \mathrm{BC}$ & 2 & 0.14 \\
\hline M/LBA & $2200 / 2100-1100 \mathrm{BC}$ & 40 & 4 \\
\hline Ha A-B & $1100-750 \mathrm{BC}$ & 4 & 1.14 \\
\hline Ha C-D & $750-400 \mathrm{BC}$ & 7 & 2 \\
\hline Lt B-C & $400-125 \mathrm{BC}$ & 3 & 1.5 \\
\hline Lt D & 125 BC-AD 106 & 3 & 1.5 \\
\hline Roman period & $106-300$ AD & 5 & 2.5 \\
\hline Migration period & $300-900 \mathrm{AD}$ & 3 & 0.42 \\
\hline Middle Age & $900-1400 \mathrm{AD}$ & 100 & 20 \\
\hline
\end{tabular}

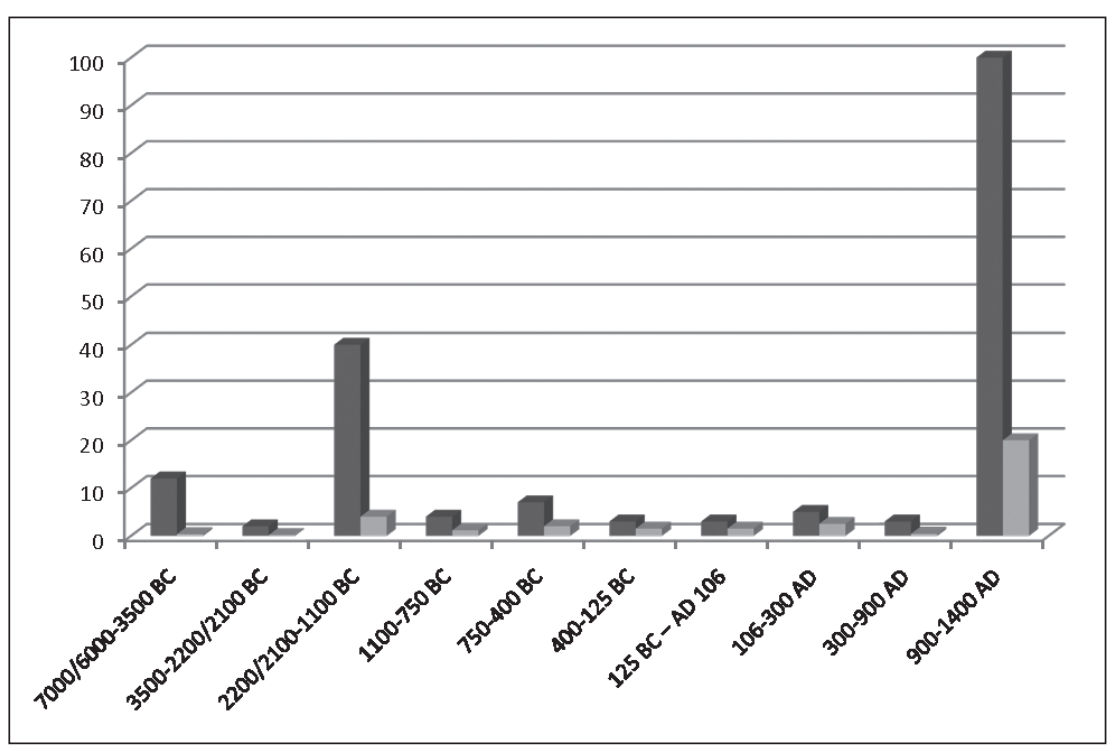

At the beginning of the Iron Age, in the Hallstatt A-B phases, the total number of settlements was again drastically reduced in Maramureş. Still, the period was also marked by the appearance of new social features. Four settlements were identified around Sighet and along the Iza valley, leading to an average number of 1.14 sites per century. All of them were ascribed to the Gáva culture. Large areas in Maramureş, like the Vişeu valley or the valleys to the right side of the Tisza River, seem to be uninhabited during this period (Fig. 4: 1). The settlements from Bârsana, Bogdan Vodă and Onceşti, located on the Iza's terraces, had similar rural features to those of the previous period. On the other hand, one settlement fortified with an earth rampart and a ditch was partially investigated through systematic excavations at Sighetu Marmației-Dealul Cetății. The site is located on a hill with a height of $513 \mathrm{~m}$, well above the $274 \mathrm{~m}$ altitude of the modern town, dominating both the Tisza and the Iza valleys (Fig. 5: 1). This fortified settlement illustrates the appearance of new social features, among them being a social 
hierarchy that differs from the previous rural social models. At the same time, it is also reflecting a new manner of organizing the surrounding territory and exploiting the economic resources in spite of a demographic decreasing in comparison with the previous period.
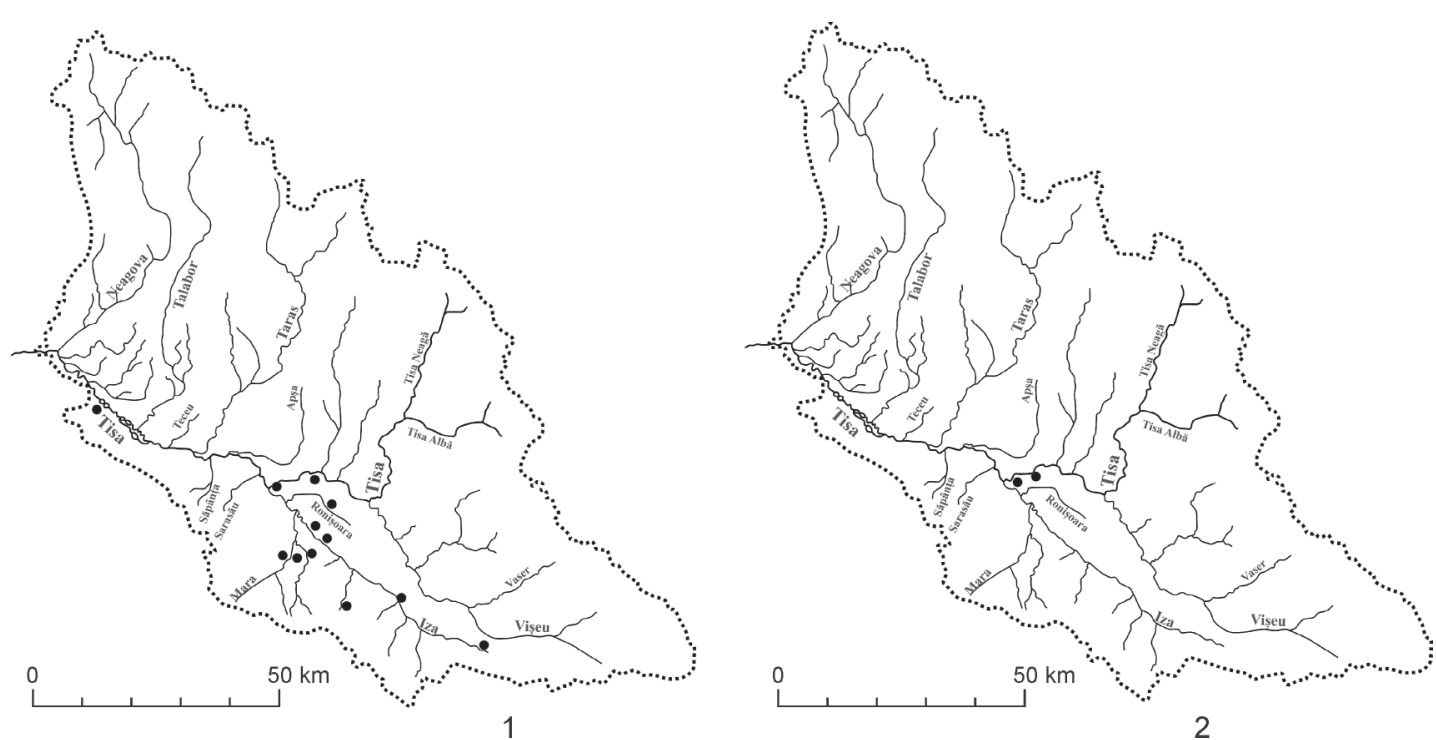

Fig. 2. 1 - Distribution of settlements in Maramureş during the Neolithic. 2 - Distribution of settlements in Maramureş during the early Bronze Age.

The middle and late phases of the Early Iron Age (Hallstatt C-D) are marked by a slight demographic increasing. This pattern could indicate a natural demographic development and a continuity of the communities from the previous period. Moreover, this continuity is also suggested by the perpetuation of certain ceramic forms and types of sets of vessels which appeared in the previous period. Seven archaeological sites which can be dated to this period were identified, with an average number of two sites per century. These are again concentrated around Sighet, on both banks of the Tisza River, although some also appeared sporadically on the Iza valley. One cremation burial in urn which was accidentally discovered at Hust indicates the probably presence of a contemporaneous settlement in the vicinity (Fig. 4: 2). These rural settlements are located on the terraces of main rivers or on lateral valleys. Similarly to the previous period, some settlements were fortified, for example Belaja Cerkov' (Fig. 5: 2;

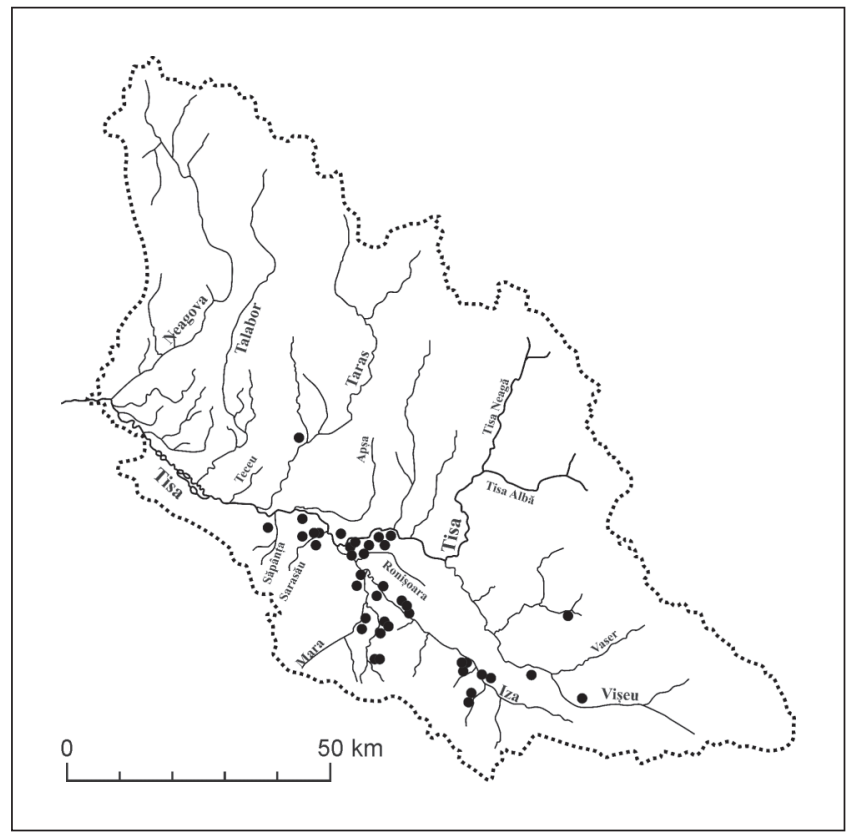

Fig. 3. Distribution of settlements in Maramureş during the middle and late Bronze Age (Suciu de Sus culture). Biserica Albă - Vasiliev 2003; 2007), which may suggest a similar type of social organization and the use of similar strategies regarding the exploitation of economic resources.

During the following centuries $\left(4^{\text {th }}-3^{\text {rd }}\right.$ centuries BC), corresponding to the early and middle phases of the Late Iron Age, two settlements fortified with a rampart and ditch are attested at Solotvino (Slatina) and Belaja Cerkov' (Fig. 5: 2; 6: 1; Rustoiu 2008, 80-86). The fortified settlement at Seredne Vodiane (Apşa 
de Mijloc)-Beşicură could also be added due to its layout which seems to belong to the same period (Fig. 4: 3). The average number of 1.5 sites per century is close to that of the previous period. These settlements are located on the high terrace on the right bank of the Tisza River (Solotvino) and on a cut bank which is a few $\mathrm{km}$ upstream (Belaja Cerkov'). The absence of rural settlements in the vicinity or in the hinterland of these fortified settlements is more likely the result of the current state of archaeological research. The settlements are again concentrated on the lowlands of the Sighet section of the Tisza River, while this kind of discoveries are apparently missing from most of the Maramureş depression.

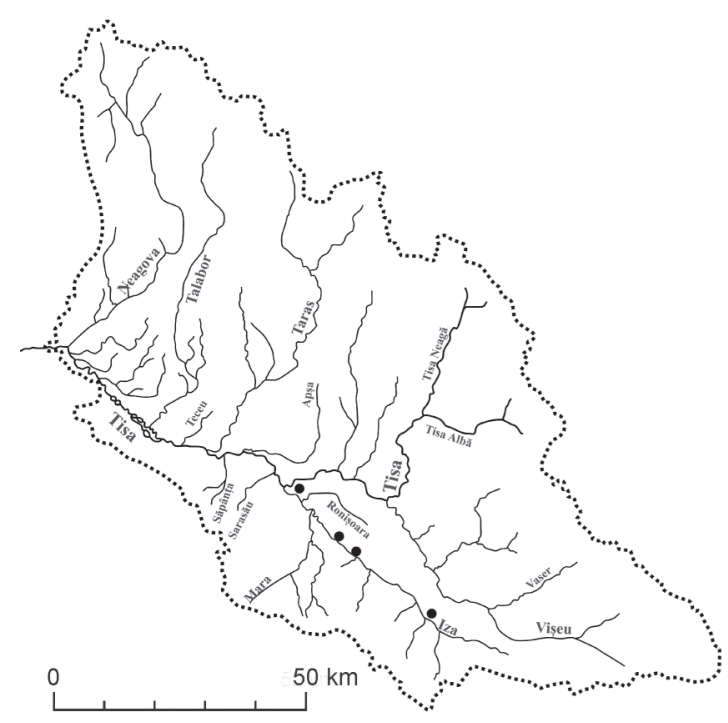

1

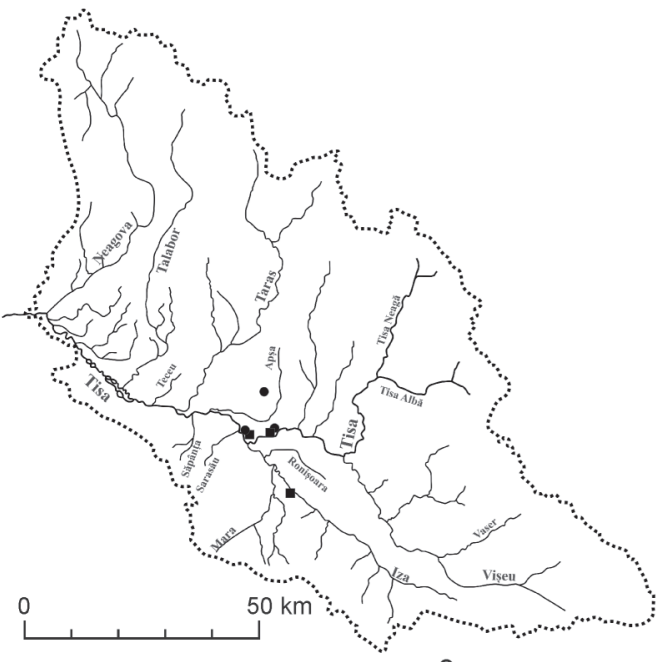

3

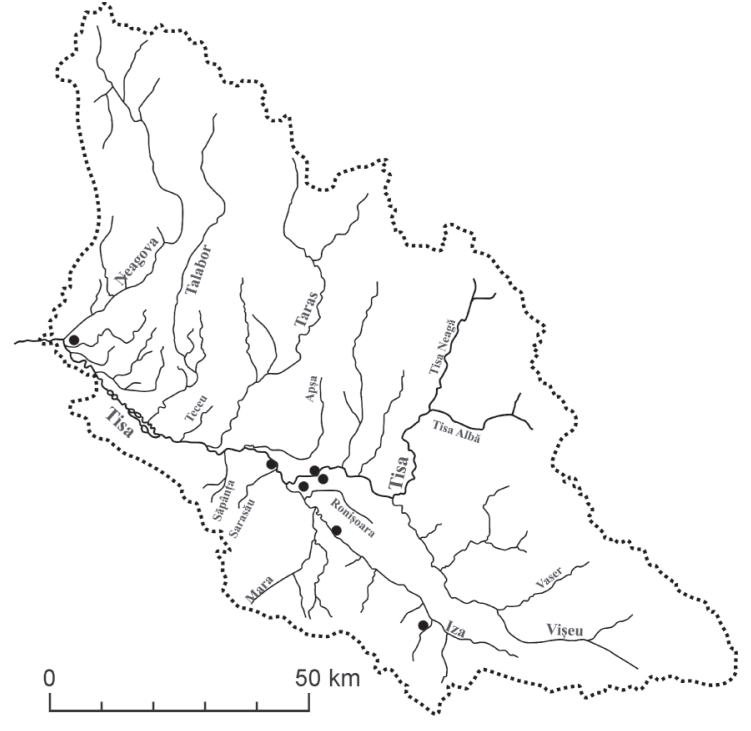

2

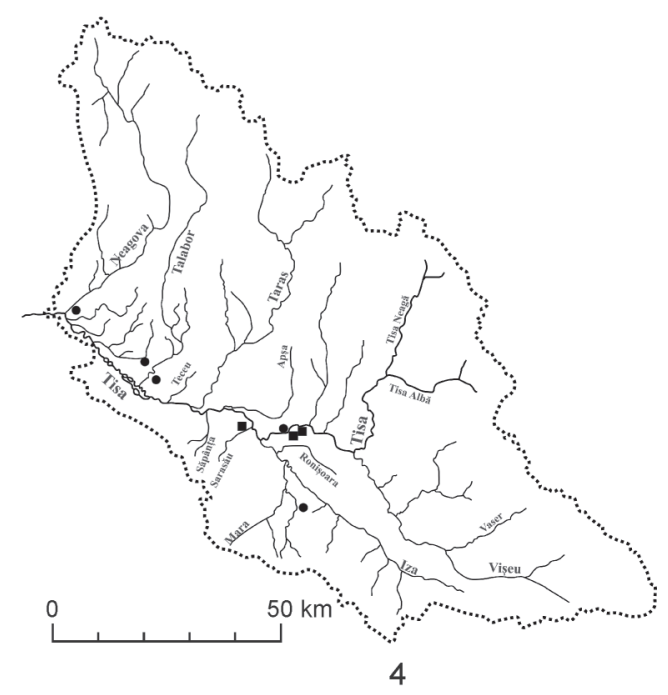

Fig. 4. Distribution of settlements in Maramureş. 1 - Ha A-Ha B; 2 - Ha C-Ha D; 3 - Lt B-Lt C (black dots) and Lt D (black squares); 4 - Roman period (black dots) and Migration period (black squares).

There are no major changes during the following period at the end of the Late Iron Age (Fig. 4: 3 ). This is largely covering the $2^{\text {nd }}$ century $B C-1^{\text {st }}$ century $A D$, corresponding to the existence of the Dacian kingdom. The settlements belonging to this period include archaeological layers and complexes superposing the earlier-dated habitations at Solotvino (Slatina) and Belaja Cerkov' (Biserica Albă). In the first case, the intensive habitation is represented by a consistent archaeological layer and numerous 
dwellings. The earlier fortification consisting of a ditch, rampart and palisade was reinforced during this period, while the settlement also extended outside the enclosure, on the terrace from the close vicinity (Fig. 6: 1). At Belaja Cerkov' (Biserica Albă), the corresponding habitation had a sporadic character and it wasn't fortified during this phase. One small fortress located on a hilltop at Onceşti, on the Iza valley, can also be added. The average number of settlements per century is identical to the one of the previous period, suggesting a constant, linear evolution of the communities from Maramureş throughout the entire Late Iron Age, without major demographic changes.

However the Roman period, largely covering the $2^{\text {nd }}-3^{\text {rd }}$ centuries $\mathrm{AD}$, witnessed a series of both demographic and ethno-cultural changes. A single rural settlement is known during this period at Călineşti-Rogoaze, on the Cosău valley, being probably dated to the $3^{\text {rd }}$ century AD. During the same period, a series of tumulus cremation burials appeared on the northern bank of the Tisza River between Belaja Cerkov' (Biserica Albă) and the Iza River, near Hust, pointing to the arrival of new populations in the region (Fig. 4: 4). These cemeteries were ascribed to the so-called culture of the Carpathian tumuli. Their inventories contain wheel-made ceramic vessels which were produced by a series of workshops in the Barbaricum, though by Roman craftsmen or locals trained in the Roman provincial environment. In some cases the vessels were accompanied by weaponry or elements of military equipment of the Przeworsk type, which might suggest that the elites of these communities consisted of Germanic warriors. Although the average number of 2.5 sites per century is slightly higher than in the previous period, more likely due to the arrival of the aforementioned groups of population from the north or north-west along the Tisza River, most of the Maramureş depression still remained uninhabited during this period.

Later during the $1^{\text {st }}$ millennium $\mathrm{AD}$, the demographic density was drastically
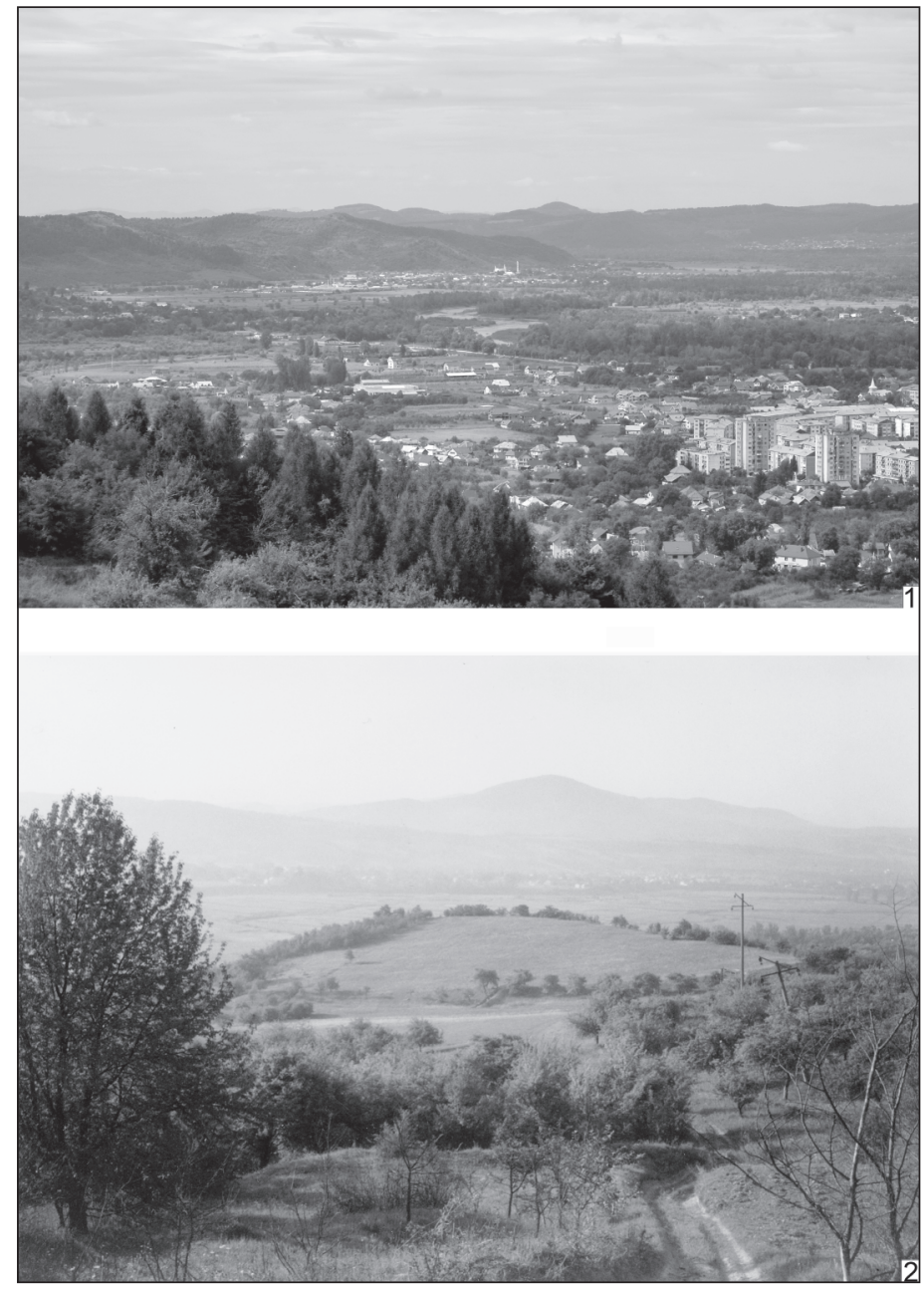

Fig. 5. 1 - Overview of the Tisza valley from the fortified settlement at Sighet. 2 - The fortified settlement at Belaja Cerkov' (Biserica Albă). reduced, with the average number of sites per century falling to 0.42 . During this period the Maramureş depression was basically uninhabited. The few settlements identified at Crăciuneşti-Mohelca, Sarasău-Zăpodie and Tisa-Lazuri/Certeze belong to the $4^{\text {th }}-7^{\text {th }}$ centuries AD. They are located on the southern bank of the Tisza River or on the nearby lateral valleys, in the same areas where other settlements functioned during the previous periods, indicating a preference for a particular environment which was more favourable for habitation (Fig. 4: 4).

Lastly, the beginning of the Middle Age was characterized by an unprecedented demographic expansion across the entire Maramureş depression. Initially, some fortresses were established in the $12^{\text {th }}-13^{\text {th }}$ centuries at Solotvino (Slatina), Onceşti and Sarasău, followed by numerous villages which were attested in the $14^{\text {th }}-15^{\text {th }}$ centuries, being mentioned in medieval documents (see further in Popa 1970). In the period between ca. 900 and 1400 were identified over 100 settlements, with an average number of ca. 20 sites per century. The majority of them were Romanian communities, while others located along the Tisza River between Hust and Sighet were established by colonists brought over by the Hungarian kingdom. 
Accordingly, this demographic expansion, which led to the occupation of most of the Maramureş depression (with the exception of some mountainous forested areas to the north and east, which were later colonized by the Ruthenians), was more likely initiated by the immigration of Romanian communities from the south at the beginning of the Middle Age. This was completed by communities of hospites colonized by the Hungarian kingdom.

\section{MINERAL RESOURCES AND THE ANTHROPIC ENVIRONMENT}

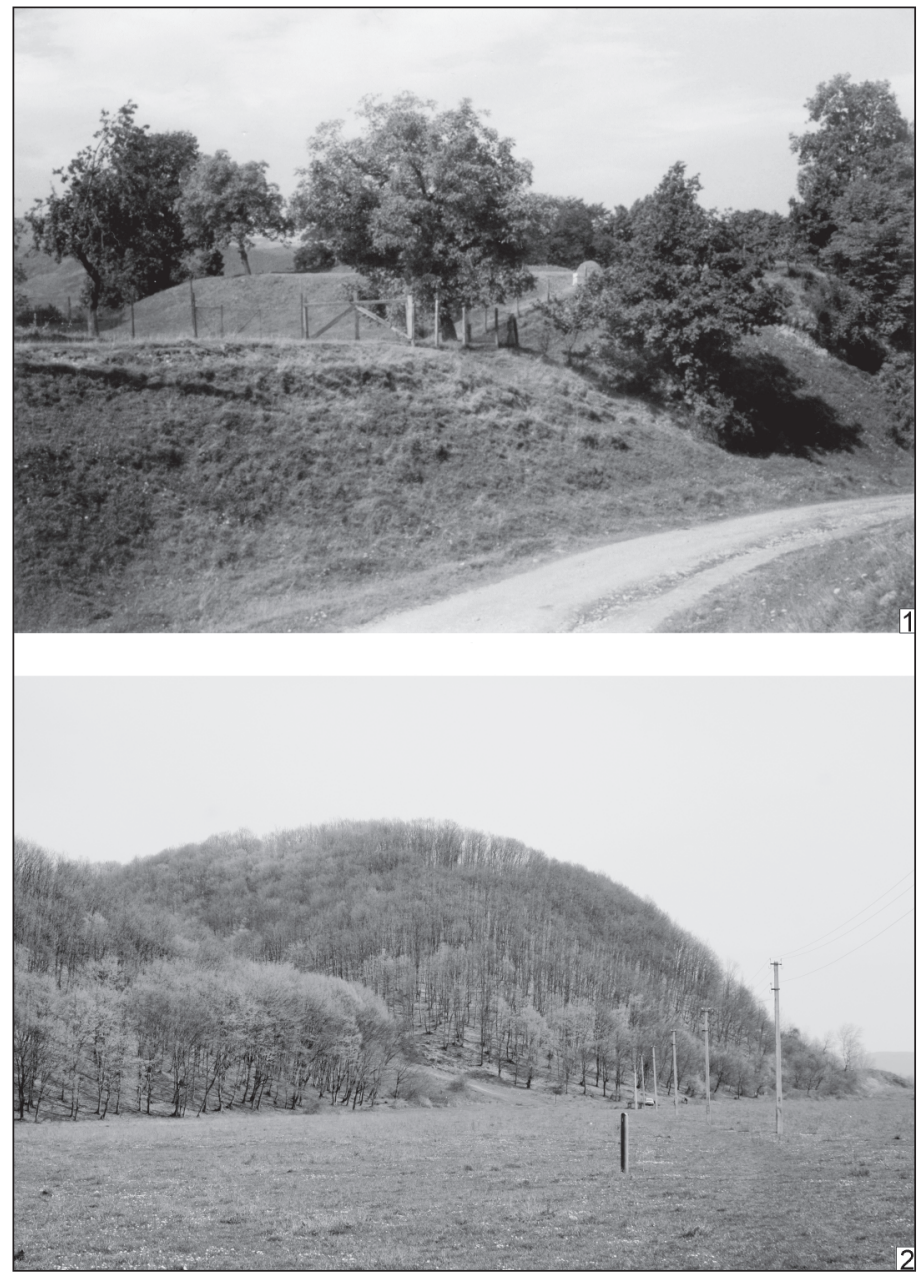

Fig. 6. 1 - The fortified settlement at Solovino (Slatina). 2 - The fortified settlement at Malaja Kopanija dominating the Tisza valley as it leaves the Maramureş depression.
The manner in which human habitats are spatially distributed was also determined by the available natural resources in the Maramureş depression. The intensity of exploitation and the range of resources used by different communities had changed from one period to another. Among the mineral resources that more likely had economic relevance were nonferrous metal ores and salt.

Complex copper ores associated with zinc, lead and silver were identified in the south-eastern part of the Maramures depression. Gold resources were identified in the south and also along the Tisza River, in the Rachiv massif (Kacsó 2011a, 78-82; 2013, 225, 226). However, it is difficult to ascertain how much of these resources were exploited and which was the intensity of the related economic activities during different historical periods.

The areas including these mineral resources seem to have been more densely inhabited only during the Bronze Age. On the other hand, 60 deposits containing bronze objects sometimes associated with gold items were discovered in the Maramureş depression, being dated mostly to the late Bronze Age, but also to the early Hallstatt period; numerous bronze and gold artefacts belonging to the same period was also found isolated (Kacsó 2013, 226, 227, fig. 2). Accordingly, it might be presumed that some of these metal ores were exploited through opencast mining mostly at the end of the Bronze Age and the beginning of the Early Iron Age, though direct archaeological evidence (open-cast pits dated by archaeological finds, smelting kilns etc) are lacking so far. The large-scale exploitation of these resources is only documented from the end of the Middle Age and the beginning of the modern times (Kacsó/Işstvan/Minghiraş 2008-2009). A series of bronze deposits contain fragmentary moulds or metal ingots which indicate the existence of workshops manufacturing bronze objects (Kacsó 2013). However, it is difficult to ascertain whether the raw metal was obtained from Maramures ores or it was sourced from elsewhere as ingots. Nevertheless, it is quite clear that the distribution area of these deposits largely corresponds to the regions in which settlements belonging to the Suciu de Sus culture are also attested during the Bronze Age. At the same time, a significant concentration of bronze deposits 
containing gold objects was noted during the early Hallstatt period in the Sighet region, on both banks of the Tisza River, including a large fortified settlement which probably functioned as a regional centre of power.

Returning to the natural resources from the Maramureş depression, salt more likely played the most important economic role. Again, direct arguments for the exploitation of salt during different historical periods are scarce and the effects of its economic exploitation can mostly be presumed. Surface deposits of rock salt are numerous in the Maramureş depression. They are present at Ocna Şugatag, Coştiui and Slătioara, south of the Tisza River, or at Solotvino (Slatina) and Nereşniţa to the north. At the same time, numerous springs having a high concentration of salt are known along the Iza and some of its tributaries, as well as in some valleys to the north of the Tisza (Kacsó 2011a, 83; Kacsó 2013).

In 1817, in a salt mine opened by the Austrian authorities close to Nereşniţa were found wooden tools and installations used to extract salt. The radiocarbon and dendro-chronological dating of these objects indicated that the majority of them belong to the $12^{\text {th }}-10^{\text {th }}$ centuries $B C$, while a single artefact (a wooden ladder) was dated later, to the $8^{\text {th }}-10^{\text {th }}$ centuries AD (Harding 2011). Similar tools and installations dated to the end of the Bronze Age or the beginning of the Hallstatt period were also found in Transylvania at Valea Florilor near Turda and Ocna Dej, and more recently at Băile Figa (Harding/Kavruk 2010).

For other historical periods there are no concrete arguments regarding the nature and intensity of exploitation. However, these can be presumed on the basis of other archaeological data corresponding to each period. For example, the manner of organizing the extraction and distribution of Maramures salt can be ascertained for the end of the Late Iron Age, during the Dacian kingdom. The settlement at Solotvino (Slatina) is located in the close vicinity of the salt resources (see Rustoiu 2002a; 2005). Thus it has been presumed that some of the main economic activities of the respective community were related to salt extraction and distribution. However, the settlement's inventories are lacking artefacts that would indicate the existence of regular long-distance economic exchanges.

On the contrary, these types of finds are more abundant in the fortified settlement at Malaja Kopanija. The settlement is located on a height on the right bank of the Tisza River, at around $60 \mathrm{~km}$ downstream from Solotvino (Slatina), in an area where the river leaves the Maramureş depression to reach the Hungarian plain (Fig. 6: 2). Due to this highly strategic position, the Dacian community from Malaja Kopanija was able to control the entire circulation along the Tisza, including the salt trade (see also the same opinion in Kotigoroško 1991, 130). Salt trade "monopoly" contributed to the economic flourishing of the settlement, which is demonstrated by the large number of "Celtic" artefacts dated to the $1^{\text {st }}$ century BC and Roman provincial goods dated to the $1^{\text {st }}$ century $\mathrm{AD}$ found on site. This level of prosperity is also reflected by the activity of numerous craftsmen, some coming from the middle Danube region. At least some of the Central European-style artefacts ("Celtic" or "Roman") were actually produced at Malaja Kopanija by these craftsmen. For example, one strongly profiled brooch of Roman type, which is halffinished, points to the activity of a bronze-working craftsman who came over from the Roman Empire, more likely from Pannonia, in the $1^{\text {st }}$ century AD. The large number of strongly profiled brooches discovered at Malaja Kopanija illustrates the scale of production of these artefacts (Kotigoroško 2002, 135-154, pl. 3; 4; Rustoiu 2002b, 79).

Lastly, the monetary circulation in the settlement at Malaja Kopanija indicates the degree of control exerted by the local elites on the distribution of natural resources and their long-distance connections. Over 130 coins were discovered on site (Kolníková/Kotigoroško 2011). These include coins of the Vel'ko Bistrec type (from northern Slovakia), Medieşu Aurit type (the most numerous group, leading to the presumption that they were issued at Malaja Kopanija), Sirmium type, Roman Republican denarii (including some issued by the colony of Nemausus in southern Gallia), drachmas of Dyrrhachium and Apollonia, one coin from Mesambria and Roman imperial coins (Kotigoroško 1991, 130). Aside from these finds, two hoards were discovered on the left bank of the Tisza (in the close vicinity of the settlement at Malaja Kopanija) at Gudja and Korolevo. The latter hoard include 11 drachmas issued by Apollonia, 12 drachmas of Dyrrhachium, 2 tetradrachmas of Thasos and 11 Roman Republican denarii (Kobal 1996, 176, fig. 18).

The control exerted by the settlement at Malaja Kopanija could explain, up to a point, the scarcity of imports from the latest Dacian layer from Solotvino-Cetate. The few finds of this kind probably reached Solotvino through a mechanism of redistribution controlled by the leaders of the community from Malaja Kopanija. This pattern could suggest a relation of subordination (political or/and economic?) of the community from Solotvino to the elites of the community from Malaja Kopanija. 


\section{CONCLUSIONS}

From the landscape's viewpoint the Maramureş depression is clearly delimited by mountain ranges having different altitudes. The region itself is fragmented by valleys cutting through a hilly landscape and forming gorges and micro-depressions. The Tisza River functions as an east - west axis across the Maramureş depression. In spite of its apparent geographic isolation, a series of mountain passes allowed the circulation of people across the mountains, thus facilitating the interactions between the communities from the Maramureş depression and those to the west, in Pannonia, or the east, in Moldova.

The local landscape also influenced the general or micro-regional climate, as well as the vegetation characteristics across the entire depression. Recent analyses have shown that the local vegetation evolved through time due to specific climatic conditions though human interventions also played an important role. The human factor had a different degree of impact on the natural environment through time, depending directly on the intensity of habitation.

It has been shown that during the middle and late Bronze Age (the $2^{\text {nd }}$ millennium $\mathrm{BC}$ ) and at the beginning of the Middle Age the Maramureş depression witnessed some demographic expansions. The total number of sites was higher than that of the previous historical periods, while the entire region was almost completely inhabited. On the other hand, the human habitation was sporadic during other historical periods, so the natural environment more likely suffered little or no human interventions. This was the case in the Neolithic, the early Bronze Age or the migrations period of the $1^{\text {st }}$ millennium AD, when large parts of the depression remained uninhabited.

From this point of view, the Iron Age shows certain particularities. The intensity of habitation throughout the $1^{\text {st }}$ millennium $B C$ and at the beginning of the $1^{\text {st }}$ millennium $A D$, reflected in the average number of sites per century, remained relatively constant though a certain demographic decreasing can be noted in comparison with the Bronze Age. This pattern suggests that the local communities largely continued to live in the same areas for a longer period, up to the beginning of the Roman period. However, it has to be noted that many settlements functioned mostly in the Sighet region, where human habitations tended to concentrate during all historical periods. Lastly, one important aspect concerns the appearance of new forms of social organization among the local communities. These include the appearance of fortified settlements in the region, pointing to the development of a social structure which differed from those of the rural societies that functioned during the periods preceding or succeeding the Iron Age. They were more likely accompanied by a new model of organizing the surrounding territory and exploiting the natural resources.

Regarding the local mineral resources, mostly non-ferrous metal ores and salt played an important role in the local economic structures. Some archaeological evidence for their exploitation is mostly available for the middle and late Bronze Age and the Iron Age. In other cases their impact can be observed indirectly in the manner of organizing the settlements and in their inventories.

\section{REFERENCES}

Corpade 2011

Dragoman et al. 2015

Fărcaş et al. 2013

Feurdean/Astaloş 2005

Feurdean et al. 2012

Hamar/Sárkány-Kiss 1999

Harding 2011

Harding/Kavruk 2010
A.-M. Corpade: Mediu real, mediu perceput şi comportament uman în depresiunea Maramureşului. Rezumatul tezei de doctorat (Universitatea 'Babeş-Bolyai' ClujNapoca, Facultatea de Geografie). Cluj-Napoca 2011. Unpublished.

R.-A. Dragoman/D. Pop/B. Bobînă/M. Ardeleanu/C. Şuteu/C. Astaloş/V. Săsăran: O arheologie a munţilor din Maramureş, România: cercetările din 2014 şi 2015. Marmatia 12, 2015, 197-234.

S. Fărcaş/I. Tanțău/M. Mîndrescu/B. Hurdu: Holocene vegetation history in the Maramureş Mountains (Northern Romanian Carpathians). Quaternary International 293, 2013, 92-104.

A. Feurdean/C. Astaloş: The impact of human activities in the Gutâiului Mountains, Romania. Studia Universitatis Babeş-Bolyai. Geologia 50/1-2, 2005, 63-72.

A. Feurdean/A. Spessa/E. K. Magyari/K. J. Willis/D. Veres/T. Hickler: Trends in biomass burning in the Carpathian region in the last 15,000 years. Quaternary Science Reviews 45, 2012, 111-125.

J. Hamar/A. Sárkány-Kiss (eds.): The upper Tisa valley. Szeged 1999.

A. Harding: Evidence for prehistoric salt extraction rediscovered in the Hungarian Central Mining Museum. Antiquaries Journal 91, 2011, 27-49.

A. Harding/V. Kavruk: A prehistoric salt production site at Băile Figa, Romania. Eurasia Antiqua 16, 2010, 131-167. 
Josephinische Landesaufnahme 2014

Kacsó 2007

Kacsó 2011a

Kacsó $2011 b$

Kacsó 2013

Kacsó/Iştvan/Minghiraş 2008-2009

Kobal 1996

Kolníková/Kotigoroško 2011

Kotigoroško 1991

Kotigoroško 1995

Kotigoroško 2002

Oancea et al. 1987

Pop 2015

Popa 1970

Popovich 1997

Posea 2005

Posea 1982

Rustoiu 2002a

Rustoiu $2002 b$

Rustoiu 2005

Rustoiu 2008

Sălăgean 2006

Sümegi 1999

Sümegi et al. 2002

Vasiliev et al. 2002

Vasiliev 2003

Vasiliev 2007

Willis et al. 1998
Josephinische Landesaufnahme (1763-1787). http://mapire.eu/de/map/firstsurvey ? lavers $=$ osm $\% 2 C 1 \% 2 C 73 \& b b o x=-34855.98638465768 \% 2 \mathrm{C} 5412335.762488477 \% 2$ C3096004.692176162\%2C6857912.84141773 [02. 09. 2014].

C. Kacsó: Hallstattzeitliche Funde in der Maramuresch. Východoslovenský pravek 8, 2007, 161-188.

C. Kacsó: Repertoriul arheologic al județului Maramureş. Baia Mare 2011.

C. Kacsó: Aşezări din epoca bronzului în Depresiunea Maramureşului. Satu Mare. Studii şi comunicări. Seria arheologie 27/1, 2011, 71-88.

C. Kacsó: Beiträge zur Kenntnis des bronzezeitlichen Metallhandwerks in der Maramuresch. In: B. Rezi/R. Németh/S. Berecki (eds.): Bronze Age Crafts and Craftsmen in the Carpathian Basin. Târgu Mureş 2013, 225-238.

C. Kacsó/D. Iştvan/T. Minghiraş: Cercetări de arheologie montană la Băile Borşa. Memoria Antiquitatis 25-26 (2008-2009), 2010, 505-536.

J. Kobal: Manche Probleme der La Tène-Kultur des Oberen Theißgebietes (Karpatoukraine). Acta Archaeologica Carpathica 33, 1996, 139-184.

E. Kolníková/V. Kotigoroško: New data about coin collection of Mala Kopanja complex. Karpatika 40, 2011, 49-68.

V. Kotigoroško: Antichitățile dacice din zona Tisei superioare. Thraco-Dacica 12, 1991, 115-132.

V. Kotigoroško: Ţinuturile Tisei superioare în veacurile III î. e. n. - IV e. n. Bucureşti 1995.

V. Kotigoroško: Brooches from Malaja Kopanya site and their chronological horizons. Karpatika 15, 2002, 135-154.

D. Oancea/V. Velcea/N. Caloianu/S. Dragombirescu/G. Dragu/E. Mihai/G. Niculescu/V. Sencu/I. Velcea: Geografia României 3. Carpaţii româneşti şi depresiunea Transilvaniei. Bucureşti 1987.

D. Pop: Contribuţii la repertoriul arheologic al județului Maramureş. Marmatia 12, 2015, 5-58.

R. Popa: Ţara Maramureşului în veacul al XIV-lea. Bucureşti 1970.

I. Popovich: Periodization and chronology of Kushtanovica type sites in the Transcarpathian region. Jósa András Múzeum Évkönyve 37-38, (1995-1996), 1997, 77-114.

G. Posea: Geomorfologia României. $2^{\text {nd }}$ Edition. Bucureşti 2005.

G. Posea: Enciclopedia geografică a României. Bucureşti 1982.

A. Rustoiu: Locuirile dacice. In: Vasiliev et al. 2002, 46-90.

A. Rustoiu: Războinici şi atizani de prestigiu în Dacia preromană. Cluj-Napoca 2002. A. Rustoiu: The salt of Maramureş and the Dacian settlements alongside of Upper Tisa. Mousaios 10, 2005, 353-367.

A. Rustoiu: Războinici şi societate în aria celtică transilvăneană. Studii pe marginea mormântului cu coif de la Ciumeşti. Cluj-Napoca 2008.

T. Sălăgean: Romanian society in the Early Middle Age $\left(9^{\text {th }}-14^{\text {th }}\right.$ Centuries AD). In: I.-A. Pop/I. Bolovan (eds.): History of Romania. Compendium. Cluj-Napoca 2006, 133-208.

P. Sümegi: Reconstruction of flora, soil and landscape evolution, and human impact on the Bereg Plain from late-glacial up to the present, based on palaeoecological analysis. In: J. Hamar/A. Sárkány-Kiss (eds.): The upper Tisa valley. Szeged 1999, 173-204.

P. Sümegi/R. Kertész/E. Hertelendi: Environmental change and human adaptation in the Carpathian Basin at the late glacial/postglacial transition. In: E. Jere$\mathrm{m} / \mathrm{K}$. T. Biró (eds.): Proceedings of the $31^{\text {th }}$ International Symposium of Archaeometry Budapest 1998. BAR International Series 1043. Oxford 2002, 171-177.

V. Vasiliev/A. Rustoiu/E. A. Balaguri/C. Cosma: Solotvino - „Cetate" (Ucraina Transcarpatică). Aşezările din epoca bronzului, a doua vârstă a fierului şi din evul mediu timpuriu. Cluj-Napoca 2002, 46-90.

V. Vasiliev: Consideraţii asupra sistemului de fortificaţie al aşezării traco-dacice de la Biserica Albă (Belaija Tserkovi), Ucraina Transcarpatică. Annales Universitatis Apulensis. Historica 7, 2003, 113-123.

V. Vasiliev: Locuirea din prima vârstă a fierului de pe „Dealul Mănăstirii”, localitatea Biserica Albă (Belaija Tserkovi), Ucraina Transcarpatică. In: S. Nemeti/F. Fodorean/E. Nemet (eds.): Dacia Felix. Studia Michaeli Bărbulescu oblata. Cluj-Napoca $2007,33-41$.

K. J. Willis/P. Sümegi/M. Braun/K. D. Bennett/A. Tóth: Prehistoric land degradation in Hungary: Who, How and Why? Antiquity 72, 1998, 101-113. 


\title{
Vývoj prírodného prostredia a l’udského osídlenia v regióne Maramureş od neolitu do raného stredoveku
}

\section{Prehlad}

\author{
Aurel Rustoiu
}

\begin{abstract}
Súhrn
Geograficky má Maramurešská kotlina členitý povrch s údoliami pretínajúcimi kopcovitú krajinu a tvoriacimi priepasti a mikrokotliny. Rieka Tisa tvorí jej východozápadnú os. Napriek zjavnej geografickej izolácii umožnila séria horských priechodov cirkuláciu l’udí cez hory a tak ulahčila interakciu medzi komunitami z Maramurešskej kotliny a komunitami sídliacimi väčšmi na západe v Panónii alebo na východe v Moldavsku.

Miestna krajina ovplyvnila aj celkové mikroregionálne podnebie, ako aj charakter vegetácie v celej kotline. Nedávne analýzy ukázali, že miestna vegetácia sa časom vyvíjala vd’aka špecifickým klimatickým podmienkam, hoci ludské zásahy takisto hrali dôležitú úlohu. Ludský faktor mal v rôznej miere dopad na prírodné prostredie a bol priamo úmerný intenzite osídlenia.

Ukázalo sa, že počas strednej a neskorej doby bronzovej (2. tisícročie pred n. 1.) a na začiatku stredoveku bola Maramurešská kotlina svedkom niekol'kých demografických expanzií. Celkový počet sídlisk bol vyšší než v predchádzajúcich historických obdobiach, ked’že celý región bol takmer úplne osídlený. Na druhej strane bolo ludské osídlenie v ostatných historických obdobiach sporadické, takže prirodzené prostredie v dôsledku l'udského zásahu pravdepodobne trpelo len málo alebo vôbec. Bolo to tak v neolite, v staršej dobe bronzovej alebo v období st’ahovania národov v 1. tisícročí n. 1., ked’ vel'ké časti kotliny zostali neobývané.

V tomto smere vykazuje doba železná isté špecifiká. Intenzita osídlenia v 1. tisícročí pred n. 1 . a na začiatku 1. tisícročia n. l., ktorá sa odrážala v priemernom počte lokalít na storočie, bola relatívne konštantná, hoci istý demografický pokles si možno všimnút pri porovnaní s dobou bronzovou. Tento vzorec naznačuje, že miestne komunity väčšinou zostávali žit v rovnakých oblastiach dlhší čas až do začiatku doby rímskej. Je však potrebné poznamenat’, že mnohé sídliská fungovali najmä v oblasti Sighetu, kde sa l’udské osídlenie koncentrovalo vo všetkých historických obdobiach. Napokon, jeden dôležitý aspekt sa týka objavenia nových foriem spoločenskej organizácie v rámci miestnych komunít. Ten zahŕňa výskyt opevnených osád v regióne, čo poukazuje na vývoj spoločenskej štruktúry, ktorá sa líšila od štruktúry vidieckych spoločností fungujúcich v obdobiach pred dobou železnou a po nej. Boli sprevádzané novým modelom organizácie okolitého územia a tažbou prírodných zdrojov.

Pokial' ide o lokálne nerastné zdroje, v miestnych ekonomických štruktúrach hrali dôležitú úlohu najmä rudy farebných kovov a sol'. Archeologické doklady o ich tažbe sa najčastejšie týkajú strednej a mladšej doby bronzovej a doby železnej. V iných prípadoch môžeme ich dopad pozorovat nepriamo v spôsobe organizovania osád a v ich materiálnej kultúre.
\end{abstract}

Obr. 1. Poloha Maramurešskej kotliny.

Obr. 2. 1 - Rozmiestnenie osád v regióne Maramureş v neolite. 2 - Rozmiestnenie osád v regióne Maramureş v staršej dobe bronzovej.

Obr. 3. Rozmiestnenie osád v regióne Maramureş v strednej a mladšej dobe bronzovej (kultúra Suciu de Sus).

Obr. 4. Rozmiestnenie osád v regióne Maramureş. 1 - HA-HB; 2 - HC-HD; 3 - LTB-LTC (čierne krúžky) a LTD (čierne štvorčeky); 4 - doba rímska (čierne krúžky) a stahohovanie národov (čierne štvorčeky).

Obr. 5. 1 - Pohl'ad na údolie Tisy z opevnenej osady Sighet. 2 - Opevnená osada Belaja Cerkov' (Biserica Albă).

Obr. 6.1 - Opevnená osada Solovino (Slatina). 2 - Opevnená osada Malaja Kopanija, ktorá dominuje údoliu rieky Tisa v mieste, kde opúšta Maramurešskú kotlinu.

Tabela 1. Štatistika osád z regiónu Maramureş v priebehu jednotlivých historických období. Čierna - počet osád/obdobie; sivá - priemerný počet/storočie.

Aurel Rustoiu, Dr. Habil.

Academia Română - Filiala Cluj-Napoca

Institutul de Arheologie şi Istoria Artei

Str. M. Kogălniceanu 12-14

RO - 400084 Cluj-Napoca

aurelrustoiu@yahoo.com 